Nidhomul Haq Vol 3 No: 1 Maret 2018

ISSN 2503-1481

\title{
MUHASABAH SEBAGAI UPAYA REHABILITASI EKS-PECANDU NARKOBA DI YAYASAN SUCI HATI PADANG
}

\author{
Ahmad Saefulloh \\ Prodi Pendidikan Agama Islam, STIT AD Jambi \\ Email: ahmad.saifullah39@gmail.com
}

\begin{abstract}
This paper aims to provide educational steps to institutions and agencies that implement rehabilitation programs of active or passive addicts of narcotics users. Institutions that make efforts to cure victims of drug abusers tend to pay less attention to the precise step that is the right step to do before the provision of materials or other religious approach programs. Drug Abuse has dangerous consequences, so the problem of drugs is classified into extra ordinary problems, ie problems that have no end. Various efforts have been made by the Government from preventive to rehabilitative. However, the problem has not yet been resolved, it increases in the next year. This mitigation effort can not be fully burdened to the government only, there needs to be synergy between government, society, parents, and related institutions in their field. This effort is one form of mutual concern that has been listed in the Narcotics Act, and planting aqidah through this muhasabah program as a preventive effort that can be done by institutions and NGOs in charge of rehabilitation of addicts. Research that the authors do is a qualitative type with qualitative descriptive analysis approach. The data of this study were collected through interviews and document analysis. The results show that there is a significant change of conscious attitude in receiving materials, direction, and other debriefing during rehabilitation process.
\end{abstract}

Key Words: Muhasabah, Rehabilitation, Ex-Addicts, Drugs

\begin{abstract}
Abstrak :Tulisan ini bertujuan memberikan langkah edukatif terhadap lembaga maupun instansi yang melaksanakan program rehabilitasi pecandu aktif maupun pasif pengguna narkotika. Instansi yang melakukan upaya penyembuhan korban penyalahguna obat terlarang ini cenderung kurang memperhatikan langkah jitu yang menjadi langkah awal yang tepat untuk dilakukan sebelum pemberian materi ataupun program-program pendekatan agama lainnya. Penyalahgunaan Narkoba memiliki akibat yang berbahaya, sehingga permasalahan tentang narkoba tergolong ke dalam masalah extra ordinary, yaitu permasalahan yang tidak ada kesudahannya. Berbagai upaya sudah dilakukan oleh Pemerintah mulai dari preventif hingga rehabilitatif. Namun demikian, permasalahan tersebut belum juga dapat diselesaikan, justru bertambah meningkat pada tahun berikutnya.Upaya penanggulangan ini tidak bisa dibebankan sepenuhnya kepada pihak pemerintah saja, perlu adanya sinergitas antara pemerintah, masyarakat, orang tua, serta lembaga-lembaga terkait dibidangnya. Upaya ini adalah salah satu bentuk kepedulian bersama yang sudah tercantum dalam Undang-undang Narkotika, dan Penanaman aqidah melalui program muhasabah ini sebagai upaya preventif yang dapat dilakukan oleh lembaga maupun LSM yang membidangi rehabilitasi para pecandu. Penelitian yang penulis lakukan adalah jenis
\end{abstract}


Nidhomul Haq Vol 3 No: 1 Maret 2018

ISSN 2503-1481

kualitatif dengan pendekatan analisis deskriptif kualitatif. Data penelitian ini dikumpulkan melalui wawancara dan analisis dokumen. Hasil penelitian menunjukkan bahwa adanya perubahan sikap sadar yang signifikan dalam menerima materi, arahan, serta pembekalan lainnya selama proses rehabilitasi.

Kata Kunci: Muhasabah, Rehabilitasi, Eks-Pecandu, Narkoba.

\section{PENDAHULUAN}

Bentuk kekhawatiran penduduk Indonesia akibat penyalahgunaan Narkoba menjadi perhatian bersama. Sedih, gusar dan ingin sekali memberantas tindak-tindak kriminalitas tersebut adalah bentuk perasaan yang tidak bisa diungkapkan lagi dengan kata. Namun demikian, negara Indonesia telah mengeluarkan UndangUndang terhadap larangan penggunaan narkoba. Larangan tersebut terdapat di dalam Undang-undang No. 35 tahun 2009 tentang narkotika bab XV pasal 111 ayat 1 dijelaskan bahwa "Setiap orang yang tanpa hak atau melawan hukum menanam, memelihara, memiliki, menyimpan, menguasai, atau menyediakan Narkotika Golongan I dalam bentuk tanaman, dipidana dengan pidana penjara paling singkat 4 (empat) tahun dan paling lama 12 (dua belas) tahun dan pidana denda paling sedikit Rp.800.000.000,00 (delapan ratus juta rupiah) dan paling banyak Rp.8.000.000.000,00 (delapan miliar rupiah). Bahkan bagi pengedar hukumannya adalah penjaran seumur hidup atau mati. ${ }^{1}$

Pasal di atas merupakan salah satu di antara pasal lainnya yang merupakan bentuk larangan terhadap seluruh lapisan masyarakat dalam hal menanam, memelihara, memiliki, menyimpan, menguasai, atau menyediakan narkotika. Dalam Undang-Undang No. 35 Tahun 2009 disebutkan bahwa narkotika adalah zat atau obat yang berasal dari tanaman, baik sintetis maupun semisintetis yang dapat

1 Undang-Undang Narkotika, (Bandung: Citra Umbara, 2005), hal. 46 menyebabkan penurunan atau perubahan kesadaran, hilangnya rasa, mengurangi sampai menghilangkan rasa nyeri dan dapat menimbulkan ketergantungan. Dari asal katanya menurut KBBI, narkotika memiliki arti obat untuk menenangkan syaraf, menghilangkan rasa sakit, menimbulkan rasa mengantuk dan merangsang. Pada awalnya narkotika digunakan sebagai alat pengobatan, adapun jenis narkotika pertama kali digunakan adalah candu atau lazim disebut madat atau opium (Kusno:2009) ${ }^{2}$. Namun seiring perkembangan zaman narkotika disalahgunakan sehingga menjadi daftar obat-obatan terlarang. Namun di lapangan, larangan tersebut kurang diperhatikan, bahkan semakin hari semakin banyak jumlah orang yang melanggar larangan tersebut. Salah satu contoh khususnya di kota Padang sendiri dalam tahun 2015 mengalami kenaikan kasus sebanyak 626 kasus penyalahgunaan narkoba. Jumlah ini lebih tinggi dibandingkan dari tahun sebelumnya (Haluan Sumbar)

Agama Islam memandang narkotika termasuk jenis khamar karena memabukkan, dan setiap sesuatu yang memabukkan sedikit ataupun banyak dinyatakan haram. Sebagaimana dikatakan oleh Ulama Fiqih Syekh Sayyid Sabiq bahwa hukum pengharaman narkotika diqiyaskan kepada khamar (Sayyid

2 Kusno Adi,. Diversi Sebagai Upaya Alternative Penanggulangan Tindak Pidana Narkotika Oleh Anak. (Malang: UMM Press, 2009). Hal. 3 
Sabiq:2009). ${ }^{3}$ Hal ini sebagaimana terdapat di dalam al-Quran surat al-Maidah: 90

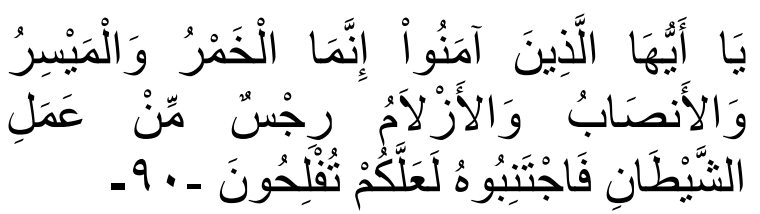

Artinya"Hai orang-orang yang beriman, Sesungguhnya (meminum) khamar, berjudi, (berkorban untuk) berhala, mengundi nasib dengan panah, adalah termasuk perbuatan syaitan. Maka jauhilah perbuatan-perbuatan itu agar kamu mendapat keberuntungan" (QS. AlMaidah/05:90).

Ayat di atas merupakan dalil alQur'an tentang keharaman narkotika, sebagaimana Sayyid Sabiq mengqiyaskannya kepada khamer. Menurut Quraish Sihab (2004) dalam tafsir alMisbah, bahwa sifat keharaman khamer baik banyak maupun sedikit tetap haram, sedikitnya khamer mengundang keinginan untuk mencoba lebih banyak hingga benarbenar merasa nikmat bagi peminumnya. Perbuatan yang demikian menurut beliau termasuk perbuatan yang bertujuan membinasakan diri, sebagaimana Allah SWT juga berfirman dalam surat lain :

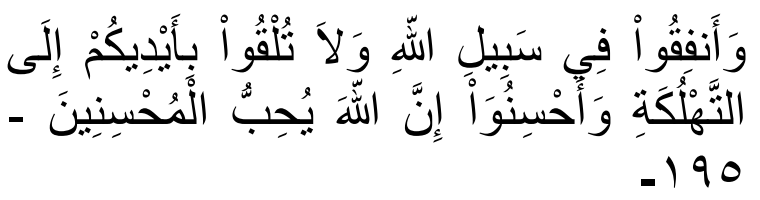

Artinya :

"Dan belanjakanlah (harta bendamu) di jalan Allah, dan janganlah kamu menjatuhkan dirimu sendiri ke dalam kebinasaan, dan berbuat baiklah, Karena Sesungguhnya Allah menyukai orang-orang yang berbuat baik" (QS. ALBaqarah/2:195).

${ }^{3}$ Sayid Sabiq,. Fiqih Sunnah. Terjemah: M. Ali Nursyidi. (Bandung: PT.Al-Ma'arif, 2009). Hal.184

4 Quraish Sihab,. Tafsir al-Misbah. (Bandung: Mizan, 2004), Hal. 231
Larangan Allah di atas agar manusia tidak berbuat sesuatu yang menjatuhkan dirinya sendiri apalagi menganiaya hingga membinasakan diri, di dalam QS. An-Nisa: 29 juga Allah SWT melarang manusia untuk membunuh dirinya sendiri, karena Allah SWT Maha Pengasih lagi Maha Penyayang, sebagaimana firman Allah SWT :

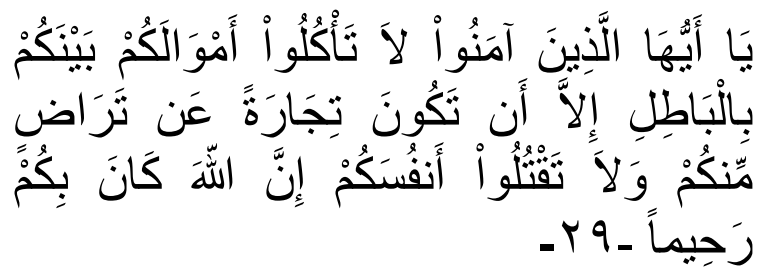

Artinya: "Hai orang-orang yang beriman, janganlah kamu saling memakan harta sesamamu dengan jalan yang batil, kecuali dengan jalan perniagaan yang berlaku dengan suka sama-suka di antara kamu. dan janganlah kamu membunuh dirimu, Sesungguhnya Allah adalah Maha Penyayang kepadamu".(QS. An-Nisa/4:29).

Ayat-ayat di atas, merupakan larangan Allah terhadap minum khamar, berjudi, menyembah berhala, dan mengundi nasib. Kaitannya dengan Narkotika dalam ayat di atas bahwa Narkotika termasuk sejenis benda yang memabukkan, dalam hal ini Sayyid Sabiq mengkiyaskan hukumnya kepada meminum khamar, yaitu sesuatu yang memabukkan, apakah itu Bir, Kiwi, Wisky, maupun jenis miras lainnya yang memiliki kadar alkohol tertentu sehingga membuat seseorang mabuk dan hilang akal serta kesadaran yang berdampak pada kebinasaan dirinya sendiri.

Hadits Nabi Muhammad SAW juga mengatakan : Dari Abu Hurairah r.a., Nabi Muhammad SAW bersabda :

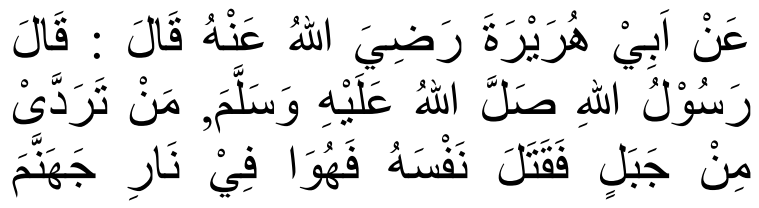




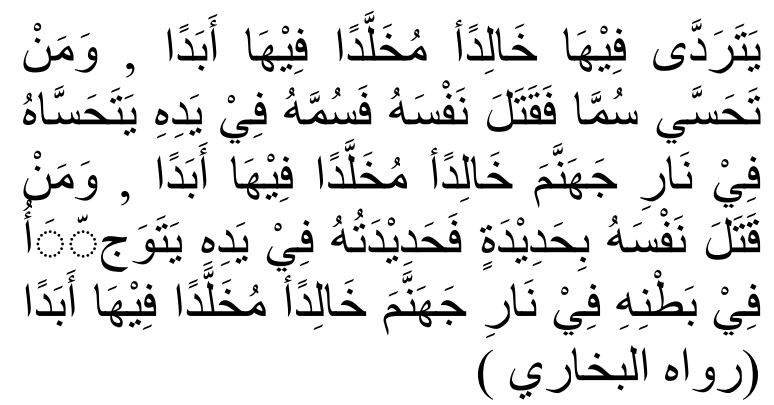

Artinya :

"Barangsiapa yang sengaja menjatuhkan dirinya dari gunung hingga mati, maka dia di Neraka Jahannam dalam keadaan menjatuhkan diri di Gunung dalam Neraka itu, kekal selama lamanya. Barangsiapa yang sengaja menenggak racun hingga mati maka racun itu tetap di tangannya dan dia menenggaknya di dalam Neraka Jahannam dalam keadaan kekal selama lamanya. Dan barangsiapa membunuh dirinya dengan besi, maka besi itu akan ada di tangannya dan dia tusukkan ke perutnya di Neraka Jahannam dalam keadaan kekal selama lamanya" (HR. Bukhari/ 5778). ('Abd al-'Aziz ibn Abdillah ibn 'Abd al-Baz: 2005) ${ }^{5}$

Hadits di atas menunjukkan akan ancaman yang amat keras bagi orang yang menyebabkan dirinya sendiri binasa. Mengkonsumsi narkoba tentu menjadi sebab yang bisa mengantarkan pada kebinasaan, karena narkoba hampir sama halnya dengan racun. Sehingga hadits ini pun bisa menjadi dalil haramnya narkoba. Larangan agama tersebut melahirkan aturan-aturan tentang larangan penyalahgunaan narkoba, sekalipun ada yang berdalih boleh mengkonsumsi narkoba jika digunakan sebagai obat, namun segi mudharatnya lebih banyak dari manfaatnya. Keadaan ini hanya dibolehkan jika dalam keadaan benar-benar darurat. Sesuai dengan pendapat Imam Nawawi rahimahullah bahwa " seandainya dibutuhkan untuk mengkonsumsi sebagian narkoba untuk meredam rasa sakit ketika

5 Abd al-Baz,. Tahqiq Shahih al-Bukhari. (Beirut: Dar al-Fikr, 2005). Hal. 249 mengamputasi tangan, maka ada dua pendapat dikalangan Syafi'iyyah, yang tepat adalah dibolehkan". Namun, hal itu hanya berlaku jika tidak ada obat yang digunakan oleh praktisi kesehatan seperti yang digunakan oleh rumah sakit.

Dalil di atas menunjukan larangan penyalahgunaan narkoba, apalagi jika pengguna mengkonsumsi narkoba dengan alasan menghilangkan stress, atau membuat obat penghilang rasa gelisah. Justru alasan yang demikian menjadi langkah awal seseorang menjadi pecandu, dengan sering mengkonsumsi maka efek ketergantunganpun menjadi semakin dekat. Dr. Syamsuridzal $(2006)^{6}$ mengatakan salah satu penyebab sulitnya pengguna narkotika untuk berhenti menggunakan obat-obatan adalah akibat rasa candu dan ketergantungan yang kuat, ditambah lagi faktor pergaulan sesama pengguna.

Seseorang yang tergabung ke dalam kelompok pemakai, jika dirinya ingin berhenti menggunakan obat, maka dampak terburuk bagi dirinya adalah tidak ada pengakuan dari kelompok, dengan demikian terkadang seseorang yang sudah lama berhenti bisa releapse (kembali mengkonsumsi) jika sudah bergabung dengan kelompoknya. Jadi, faktor pergaulan sangat mempengaruhi proses penyembuhan pecandu.

\section{HAKIKAT REHABILITASI}

Menurut Kamus Besar Bahasa Indonesia (2008), rehabilitasi adalah pemulihan kepada kedudukan (keadaan, nama baik) yg dahulu (semula), serta perbaikan anggota tubuh yg cacat dsb atas individu seperti pasien rumah sakit, korban bencana supaya menjadi manusia yg berguna dan memiliki tempat di dalam masyarakat.

Berdasarkan definisi tersebut, tentu harapan setiap orang adalah mendapatkan kedudukan di dalam masyarakat, serta

${ }^{6}$ Syamsuridzal,. Keluarga Anti Narkoba. (Jakarta: Kompas Press, 2006). Hal. 34 
pengakuan kembali status normalnya untuk terlibat di setiap aktivitas lingkungan adalah keinginan yang paling besar. Keinginan pecandu untuk berhenti adalah langkah yang paling efektif dalam proses pengobatan dan rehabilitasi (pernyataan Muhammad Ali Azhar, Sumatera Metropolitan, (Padang), 18 September 2015). Pernyataan ini disampaikan oleh ketua BNNP Sumbar dalam seminar P4GN di aula kantor Gubernur. Pada kesempatan itu beliau juga menghimbau kepada seluruh pecandu agar segera melapor kepada IPWL (Instansi Penerima Wajib Lapor) yang sudah ditunjuk untuk mengatasi para pecandu yang ingin berhenti. Adapun jumlah IPWL yang siap menerima pengaduan dari pecandu di Sumbar saat ini sudah berjumlah 13 lembaga di bawah Kemenkes dan 3 di bawah naungan Kemensos. Beliau juga menambahkan dalam himbauannya tersebut, bahwa "Untuk pecandu tidak ada pidana melainkan rehabilitasi. Jadi, tidak perlu takut melapor karena kami akan membantu memulihkan para pecandu supaya bisa lepas dari narkoba. Tapi sayangnya selama ini pasal tentang narkoba sering dimainkan, hingga para pecandu narkoba takut melapor padahal kita sudah menyiapkan rehabilitasi untuk kebaikan para pecandu".

Berdasarkan himbauan ketua BNNP Sumbar di atas, pasal tentang rehabilitasi juga sudah tercantum di dalam UndangUndang Narkotika nomor 35 tahun 2009 pasal 54 tentang narkotika menyatakan bahwa "Pecandu narkotika dan korban penyalahgunaan narkotika wajib menjalani rehabilitasi medis dan rehabilitasi sosial". Dalam Bab I tentang ketentuan umum disebutkan :

Pasal 1 butir 16 Undang-undang Nomor 35 tahun 2009 menyatakan bahwa; "rehabilitasi medis adalah suatu proses kegiatan pengobatan secara terpadu untuk membebaskan pecandu dari ketergantungan narkotika".
Pasal 1 butir 17 Undang-undang Nomor 35 tahun 2009 menyatakan bahwa; "rehabilitasi sosial adalah suatu proses kegiatan pemulihan secara terpadu, baik fisik, mental, maupun sosial, agar bekas pecandu narkotika dapat kembali melaksanakan fungsi sosial dalam kehidupan masyarakat”.

Pasal di atas kemudian dikembangkan lagi untuk menjelaskan rehabilitasi sosial. Bahwa salah satu bentuk rehabilitasi sosial adalah melalui rehabilitasi keagamaan sebagaimana tercantum di dalam pasal 57 bahwa "selain melalui pengobatan dan/atau rehabilitasi medis, penyembuhan pecandu narkotika dapat diselenggarakan oleh instansi pemerintah atau masyarakat melalui pendekatan keagamaan dan tradisional". Terkait masalah rehabilitasi, BNN mempunyai Deputi yang khusus menanganinya yaitu Deputi bidang rehabilitasi. Hal ini dapat dilihat pada pasal 20 ayat (1) Peraturan Presiden Republik Indonesia Nomor 23 Tahun 2010 tentang Badan Narkotika Nasional yang menyatakan bahwa "Deputi bidang rehabilitasi adalah unsur pelaksana sebagian tugas dan fungsi dibidang rehabilitasi berada di bawah dan bertanggung jawab kepada Kepala BNN". Deputi bidang rehabilitasi mempunyai tugas melaksanakan Pencegahan, Pemberantasan, Penyalahgunaan dan Peredaran Gelap Narkotika (P4GN) khusus dibidang rehabilitasi, hal ini sesuai dengan pasal 21 Peraturan Presiden Nomor 23 Tahun 2010 tentang Badan Narkotika Nasional. Dari peraturan ini mulai tegaslah bahwa larangan penyalahgunaan narkoba menjadi sebuah kebijakan negara yang harus di patuhi.(Lihat BNNP: 2010) ${ }^{7}$

7 Badan Narkotika Propinsi Sumatera Barat.. Kebersamaan Memerangi Penyalahgunaan dan Peredaran Gelap Narkoba. (Padang: BNNP, 2010) 
Nidhomul Haq Vol 3 No: 1 Maret 2018

ISSN 2503-1481

PEMBAHASAN TENTANG KONSEP NARKOBA

Secara umum konsep narkoba yang penulis uraikan terfokus pada definisi, macammacam narkoba, faktor penyebab penyalahgunaan narkoba, dan manfaat serta mudharat penyelahgunaan narkoba.

\section{Pengertian Narkoba}

NARKOBA adalah singkatan dari Narkotika, Psikotropika dan Bahan Adiktif lainnya. Istilah ini adalah gabungan dari obat-obatan yang bersifat kimiawi dapat mengubah suasana hati dan pikiran. Dalam hal ini, dr. Samsuridjal memberi definisi bahwa Narkoba adalah zat-zat kimiawi yang kalau dimasukkan ke dalam tubuh manusia baik secara oral ataupun lewat mulut, dihirup atau disuntik (intravena), dapat mengubah pikiran, suasana hati atau perasaan, dan perilaku seseorang Syamsuridzal, (2006). ${ }^{8}$ Kebanyakan zat dalam narkoba sebenarnya digunakan untuk pengobatan dan penelitian. Penyalahgunaan narkoba adalah pemakaian obat dan zat-zat berbahaya lain dengan maksud bukan untuk tujuan pengobatan atau penelitian serta digunakan tanpa mengikuti aturan serta dosis yang benar. Penggunaan terusmenerus dan berlanjut akan mengakibatkan ketergantungan atau dependensi, istilah ini yang sering disebut "kecanduan".

\section{Macam-Macam Narkoba}

Berbagai jenis obat-obatan narkotika yang beredar di Jakarta menurut Polda Metro Jaya adalah heroin, ganja, morfin, candu, hasis, ekstasi, sabu-sabu, psikotropika golongan IV. Namun, secara umum jenis obat-obatan dan narkotika yang dikenal di dunia antara lain LSD (Lysergic Acid Diethylamide), amphetamhine, nitrit/popper, opiade/heroin, cannabis (termasuk dalam kategori ganja), kokain, steroid, MDMA (ecstasy), ketamine, dan lainnya (Syamsuridzal: 102). Berdasarkan

${ }^{8}$ Syamsuridzal,. Keluarga Anti Narkoba. (Jakarta: Kompas Press, 2006). Hal. 102 keterangan di atas, Sudarsono mengatakan dikutip dari Pasal 1 Undang-Undang No. 9 tahun 1976, bahwa jenis-jenis zat yang temasuk narkotika adalah :

a. Tanaman Papaver somniferum $L$, termasuk biji, buah dan jeraminya.

b. Opium mentah, adalah getah yang membeku sendiri, diperoleh dari tanaman Papaver somniferum $L$ yang hanya mengalami pengolahan sekedar untuk pembungkusan dan pengangkutan tanpa memperhatikan kadar morfinnya.

c. Opium masak adalah:

1) Candu, yakni hasil yang diperoleh dari opium mentah melalui suatu rentetan pengolahan, khususnya dengan pelarutan, pemanasan dan peragian, dengan atau tanpa penambahan bahan-bahan lain dengan maksud mengubahnya menjadi suatu ekstrak yang cocok untuk pemadatan.

2) Jicing, yaitu sisa-sisa dari candu setelah dihisap tanpa memperhatikan apakah candu itu dicampur dengan daun atau bahan lain.

3) Jicingko, yaitu hasil yang diperoleh dari pengolahan jicing (BNK Padang: 2015). ${ }^{9}$

d. Opium obat adalah opium mentah yang telah mengalami pengolahan, sehingga sesuai untuk pengobatan, baik dalam bentuk bubuk atau dalam bentuk lain atau dicampur dengan zat-zat netral sesuai dengan syarat famakoope.

e. Morfin adalah alkoloida utama dari opium, dengan rumus kimia $\mathrm{C}_{17} \mathrm{H}_{17} \mathrm{NO}_{3}$.

f. Tanaman koka, adalah tanaman dari semua jenis erythroxylon dari keluarga erythroxylaceace.

g. Daun koka adalah daun yang belum atau sudah dikeringkan atau dalam

\footnotetext{
${ }^{9}$ BNK Padang,. Buku Panduan "Pencegahan Penyalahgunaan Peredaran Gelap Narkotika. (Padang: BNK Padang, 2015). Hal. 5
} 
bentuk serbuk dari semua tanaman jenis erythroxylon dari keluarga erythroxylaceace yang menghasilkan kokain secara langsung atau melalui perubahan kimia.

h. Kokaina mentah adalah semua hasil yang diperolah dari daun koka yang dapat diolah secara langsung untuk mendapatkan kokaina.

i. Kokaina adalah Metil Ester I - Bensoil Ekgonina dengan rumus kimia $\mathrm{C}_{17} \mathrm{C}_{21} \mathrm{NO}_{4}$.

j. Ekgonina adalah I - Ekgonina dengan rumus kimia $\mathrm{C}_{9} \mathrm{H}_{55} \mathrm{NO}_{32} \mathrm{O}$ dan Ester serta turunannya yang dapat diubah menjadi ekgonia dan kokaina.

k. Tanaman ganja adalah semua bagian dari semua tanaman genus cannabis termasuk biji dan buahnya

1. Daun ganja adalah damar yang diambil dari tanaman ganja termasuk hasil pengolahannya, yang menggunakan damar sebagai bahan dasar

m. Garam-garam dan turunan-turunan dari morfin dan kokaina

n. Bahan lain baik alamiah, sintesis, maupun semi sentesis yang belum disebutkan yang dapat dipakai sebagai pengganti morfin atau kokaina, yang ditetapkan oleh Menteri Kesehatan sebagai narkotika, apabila penyalahgunaan dapat menimbulkan akibat ketergantungan yang merugikan seperti morfin atau kokaina.

o. Campuran-campuran dan seduhanseduhan yang mengandung bahan adiktif (Sudarsono: 2008) ${ }^{10}$.

\section{Manfaat dan Mudharat Narkoba}

Macam-macam narkoba di atas merupakan obat-obatan yang memiliki manfaat dan mudharat jika ditinjau dari sudut pandang tertentu. Dalam hal ini narkoba memang memiliki dua sisi yang

${ }^{10}$ Sudarsono,. Kenakalan Remaja; Prevensi, Rehabilitasi, dan Resosialisasi. (Jakarta: Rineka Cipta, 2008). Hal. 70 sangat antagonis, pertama narkoba dapat memberi manfaat besar bagi kepentingan hidup dengan beberapa ketentuan. Kedua, narkoba dapat membahayakan pemakainya karena efek negatif yang ditimbulkan. Dalam kaitan ini Pemerintah Republik Indonesia telah membuat garis-garis kebijaksanaan yang termaktub dalam undang-undang No. 35 tahun 2009.

\section{Manfaat}

Kelebihan/segi positif penggunaan narkotika dapat terlihat dalam hal berikut:

1) Dalam UU narkotika bagian ketiga tentang ilmu pengetahun dan teknologi pasal 13 dikatakan bahwa:

Butir (1): Lembaga ilmu pengetahun yang berupa lembaga pendidikan dan pelatihan serta penelitian dan pengembangan yang diselenggarakan oleh pemerintah ataupun swasta dapat memperoleh, menanam, menyimpan, dan menggunakan narkotika untuk kepentingan ilmu pengetahuan dan teknologi setelah mendapatkan izin Menteri.

Butir (2) : Ketentuan lebih lanjut mengenai syarat dan tata cara untuk mendapatkan izin dan penggunaan narkotika sebagaimana yang dimaksud pada ayat (1) diatur dengan peraturan Menteri.

2) Penggunaan narkotika dengan tujuan pengobatan dalam jumlah dosis tertentu dan memiliki izin dari pemerintah memberikan manfaat kesehatan terhadap masyarakat.

\section{Mudharat}

Narkotika, selain memberikan dampak positif juga memiliki efek negatif atau dampak mudharat. Dalam hal ini para Ulama sepakat mengkiyaskan hukum pengharaman narkotika ke dalam kategori khamar, yaitu barang yang memabukkan. Sebagaimana terdapat di dalam surat alMaidah ayat 90. Ayat ini menjadi dasar penetapan dan pertimbangan bahwa narkotika memberikan dampak buruk 
terhadap agama, kesehatan dan jiwa seseorang. Menurut dr. Samsuridjal, pengaruh negatif yang ditimbulkan oleh narkotika ditinjau dari jenis narkotika yang sering digunakan.

\section{Faktor Penyebab Penyalahgunaan Narkoba}

Menurut Sudarsono (2008), ${ }^{11}$ dikutip dari pendapat Dr. Graham Blaine mengemukakan bahwa biasanya seorang remaja mempergunakan narkotika dengan beberapa sebab, yaitu:

a. Untuk membuktikan keberanian dalam melalukan tindakan-tindakan yang berbahaya seperti ngebut, berkelahi, bergaul dengan wanita dan lain-lain.

b. Untuk menunjukan tindakan menentang otoritas terhadap orang tua atau guru serta norma-norma sosial

c. Untuk mempermudah penyaluran dan perbuatan seks

d. Untuk melepaskan diri dari kesepian dan memperoleh pengalamanpengalaman emosional

e. Untuk mencari dan menemukan arti hidup

f. Untuk mengisi kekosongan dan kesepian/kebosanan

g. Untuk menghilangkan kegelisahan, frustasi, dan kepepetan hidup

h. Untuk mengikuti kemauan kawankawan dalam rangka pembinaan solidaritas.

i. Hanya iseng-iseng atau dorongan rasa ingin tahu.

Faktor penyabab di atas diklasifikasikan menjadi tiga, yaitu : Penyebab obat, seperti penggunaan obat tidur yang berlebihan. Penyebab lingkungan, yang meliputi hubungan keluarga dan pengaruh teman. Penyebab kepribadian, yaitu karena aspek biologis dan aspek psikologis.

11 Sudarsono,. Kenakalan Remaja; Prevensi, Rehabilitasi, dan Resosialisasi. (Jakarta: Rineka Cipta, 2008). Hal. 67

\section{Akibat Penyalahgunaan Narkoba}

Tahap penyalahgunaan narkoba antara lain :

a. Tahap coba-coba, awalnya hanya ingin tahu dan memperlihatkan kehebatan, sehingga melanjutkan ke tahap yang lebih canggih

b. Kadang-kadang atau pemakaian reguler. Maksudnya adalah setelah tahap cobacoba kemudian melanjutkan pemakaian psikoaktif sehingga menjadi bagian dari kehidupan sehari-hari, meskipun demikian karena pemakaian bahanbahan tersebut masih terbatas tidak ada perubahan mendasar yang dialami pemakai, sehingga berlanjut kepada tahap ketagihan

c. Ketagihan, pada tahap ini frekuensi, jenis, dan dosis yang dipakai meningkat termasuk bertambahnya pemakaian bahan-bahan beresiko tinggi gangguan fisik, mental, dan masalah-masalah sosial semakin jelas. Tahap ini sering disebut tahap kritis karena ada bahaya yang nyata

d. Ketergantungan merupakan bentuk ekstrem dari ketagihan, upaya mendapatkan zat psikoaktif dan memakainya secara reguler merupakan aktivitas utama sehari-hari mengalahkan semua kegiatan lain, kondisi fisik, dan mental terus-menerus menurun. Keadaan pemakai selalu membutuhkan obat tertentu agar dapat berfungsi secara wajar, baik fisik maupun psikologis. Ketergantungan fisik misalnya, badan menjadi lemah dan sendi-sendi terasa nyeri kalau tidak menggunakan obat dalam jangka waktu tertentu. Ketergantungan secara psikologis ditunjukan oleh adanya perasaan tidak percaya diri dalam pergaulan sehari-hari kalau tidak menggunakan obat.

Akibat penyalahgunaan obatobatan tersebut, penyalahguna akan mengalami kerusakan pada organ jasmani seperti otak, mata, jantung, tenggorokan, dan mulut. Kemudian kerusakan organ 
Nidhomul Haq Vol 3 No: 1 Maret 2018

ISSN 2503-1481

rohani seperti rasa gelisah, mudah marah, mudah berbohong dan lain-lain.

\section{HASIL PEMBAHASAN \\ ALTERNATIF SOLUSI MELALUI PENDEKATAN AGAMA ISLAM}

Islam memberikan batasan keras terhadap penyalahgunaan Narkoba, meskipun dalam satu segi dapat saja diperbolehkan jika dalam keadaan darurat dan sangat dibutuhkan, namun tetap mengacu ke dalam konteks as-sadd adzaariyah-- peluang yang sangat kecil untuk diperbolehkan karena keadaan darurat dan dengan kadar tertentu-Dalam Islam jelas sekali dikatakan dalam al-Quran surat al-Maidah: 90. Ayat tersebut menjadi Undang-undang permanen dalam tata kehidupan ummat Islam terhadap batasan mengkonsumsi sesuatu yang memabukkan. Namun, bagi orang yang telah terlanjur menyalahgunakan sehingga dirinya melewati batas-batas larangan, Islam tetap memberi kepedulian dalam bentuk perhatian khusus bagi para pecandu yang benar-benar ingin bertaubat dengan cara mengendalikan sugesti dirinya. Salah satu upaya yang dapat dilakukan agar seorang yang sudah menjadi pecandu dapat mengendalikan sugestinya sendiri adalah dengan menanamkan nilai-nilai pendidikan Islam melalui pendekatan muhasabah.

\section{Pengertian Nilai}

Kata nilai berasal dari bahasa Inggris velue, yaitu harga atau sifat-sifat yang penting atau berguna bagi kemanusiaan. Nilai adalah suatu keyakinan atau kepercayaan yang menjadi dasar bagi seseorang atau sekelompok orang untuk memilih tindakannya, atau menilai sesuatu yang bermakna atau tidak bermakna bagi kehidupannya (Muhaimin: 2006). ${ }^{12}$

12 Muhaimin,. Nuansa Baru Pendidikan Islam. (Jakarta: PT. Raja Grafindo Persada, 2006). Hal. 148
Menurut Sidi Gazalba (2005) ${ }^{13}$ yang dikutip oleh Chabib Thoha mengartikan Nilai adalah sesuatu yang bersifat abstrak, ideal, nilai bukan benda konkrit, bukan fakta, tidak hanya persoalan benar dan salah yang menuntut pembuktian empirik, melainkan penghayatan yang dikehendaki dan tidak dikehendaki. Menurut Chabib Thoha, nilai adalah sifat yang melekat pada sesuatu (sistem kepercayaan) yang telah berhubungan dengan subjek yang memberi arti (manusia yang meyakini). Jadi, nilai adalah sesuatu yang bermanfaat bagi manusia sebagai acuan tingkah laku.

Berdasarkan pengertian di atas, dapat diketahui bahwa nilai merupakan sesuatu yang bersifat abstrak dan subjektif, ukurannya terletak pada masing-masing individu. Namun demikian tentu ada nilainilai umum yang berlaku universal yang diakui sebagai suatu kebenaran oleh semua orang yang tidak terbatas oleh waktu, tempat maupun agama seperti nilai kejujuran, nilai keadilan dan sebagainya. Jadi, nilai merupakan norma yang meletakkan perbuatan, cara bertingkah laku, dan tujuan pekerjaan yang dapat diterima atau yang tidak dapat diterima, yang diingini, serta yang dianggap baik atau dianggap buruk.

\section{Pengertian Pendidikan Islam}

Kata pendidikan berasal dari kata didik yang mendapat awalan $p e$ - dan akhiran -an. Menurut KBBI kata tersebut berarti perbuatan atau cara mendidik. Sedangkan secara bahasa, berasal dari bahasa Yunani, yaitu "paedagogie" yang terdiri dari kata "pais" yang berarti anak ," again atau gogos" yang berarti membimbing dan "iek" artinya ilmu (Surtito: 2000). ${ }^{14}$ Jadi, secara etimologi paedagogie adalah ilmu yang

${ }^{13}$ Chabib, H. T,. Kapita Selekta Pendidikan Islam. (Yogyakarta: Pustaka Pelajar, 2005). Hal. 90

14 Sartito,. Pengantar Psikologi. (Jakarta: Bulan Bintang, 2000), Hal. 64 
membicarakan bagaimana memberikan bimbingan kepada anak.

Ahmadi (2001) ${ }^{15}$ mengatakan pendidikan merupakan bimbingan yang diberikan kepada anak. Sedangkan menurut istilah, Ngalim Purwanto (2003) ${ }^{16}$ mengatakan bahwa pendidikan adalah bimbingan yang diberikan secara sengaja oleh orang dewasa kepada anak-anak dalam pertumbuhan jasmani dan rohaninya agar berguna bagi dirinya dan masyarakat. Dalam bahasa Inggris pendidikan diterjemahkan menjadi education. Education berasal dari bahasa Yunani "eduare" yang berarti membawa keluar yang tersimpan dalam jiwa anak, untuk dituntun agar tumbuh dan berkembang. Dalam bahasa jawa disebut "pangula wenthah" yang artinya mengolah, membesarkan, mematangkan anak dalam pertumbuhan jasmani dan rohaninya. Dalam bahasa Arab pendidikan juga diistilahkan dengan Tarbiyah, Rabban, dan Rabba yang berarti memelihara, mengasuh, menanggung, dan mengembangkan.

Menurut Naquib al-Atas diistilahkan juga dengan at-ta'lim yang berarti proses pengajaran, jika dikaitkan dengan istilah tarbiyah, ta'lim mempunyai makna pengenalan tempat segala sesuatu, sehingga maknanya lebih universal dari istilah tarbiyah, karena kata tarbiyah tidak meliputi segi pengetahuan dan hanya mengacu pada kondisi eksternal. Selain atta'lim, istilah lain dari pendidikan adalah at-ta'dib yang berarti proses pengenalan dan pengakuan secara berangsur-angsur yang ditanamkan dalam diri manusia pada tempat yang tepat dari segala sesuatu di dalam tatanan penciptaan, kemudian membimbing dan mengarahkannya pada pengakuan dan pengenalan kekuasaan dan

15 Abu Ahmadi Maududi., Dasar-Dasar Islam Terj. (Ainur Rahmah. Bandung: Pustaka, 2004). Hal. 69

16 Ngalim Purwanto,. Ilmu Pendidikan Praktis dan Teoritis. (Bandung: PT. Remaja Rosda Karya, 2003). Hal. 11 keagungan Tuhan di dalam tatanan wujud dan keberadaanya. Konsep pendidikan dari istilah ini sesuai juga dengan definisi dari Ahmad D. Marimba, bahwa pendidikan adalah bimbingan jasmani dan rohani menuju terbentuknya kepribadian utama menurut ketentuan-ketentuan yang berlaku, dan ditambahkan oleh Prof. Ramayulis bahwa proses yang ditempuh pendidikan untuk menuju manusia yang insan kamil.

Jadi, Nilai-Nilai Pendidikan Islam adalah bimbingan jasmani dan rohani oleh pendidik kepada peserta didiknya melalui keyakinan agama Islam, guna menjadi pribadi yang berakhlak mulia dan mencapai manusia yang insan kamil.

\section{Muhasabah sebagai langkah awal pendekatan Agama dalam proses rehabilitasi}

\section{A. Perencanaan}

Program Muhasabah merupakan kegiatan dengan tujuan peyadaran kesalahan melalui penyesalan akibat perbuatan yang sudah dilakukannya selama terlibat menjadi pemakai aktif. Muhasabah berasal dari kata hasaba yang berarti menghitung. Dalam hal ini, tujuan kegiatan muhasabah berarti menghitung kesalahan yang sudah dilakukan melalui renungan-renungan diri baik dilakukan secara individu maupun melalui bimbingan pengasuh dengan harapan benar-benar taubat dan tidak akan mengulangi perbuatan tersebut. Direktur Yayasan Suci Hati, Ustadz Saiful mengatakan bahwa tujuan utama program awal ini adalah kembali ke titik nol, yaitu sadar. Upaya menumbuhkan kesadaran terhadap pasien, tentang alasan mereka berada di sini, bagaimana sikap mereka selama berada di sini, serta bagaimana yang harus mereka lakukan setelah keluar 
dari sini. ${ }^{17}$ Dalam pengamatan penulis, perencanaan awal yang lakukan dalam program ini adalah langkah yang tepat sebelum memulai sebuah aktivitas. Capaian kegiatan yang akan dituju sudah terbenam di garis star pelaksanaan program, dengan begitu apapun yang akan dilakukan tetap berada pada rambu-rambu yang mengatur jalur kebenaran yang menjadi acuan pasien selama menempuh proses rehabilitasi.

\section{B. Pelaksanaan}

\section{Program}

Muhasabah

dilaksanakan satu bulan sekali setiap hari kamis. Program muhasabah ini sudah dilakukan sejak awal berdirinya Yayasan Suci Hati yang sebelumnya berbentuk LSM. Dalam pelaksanaannya, kegiatan ini dipimpin langsung oleh Direktur Yayasan Suci Hati selaku terapis keagamaan. Menurut Rila, muhasabah dilakukan setelah selesai shalat maghrib yang diikuti oleh seluruh pecandu yang direhab. ${ }^{18}$ Muhasabah diawali dengan membaca istighfar yang dipandu langsung oleh Ustadz Syaiful, kemudian pasien rehab beserta seluruh pengasuh yang hadir mengikuti bacaan tersebut hingga berulang-ulang. Kemudian, dilanjutkan membaca beberapa ayat pilihan oleh pemandu, sementara pasien rehab mendengarkan hingga selesai. Ketika muhasabah biasanya Ustadz Syaiful menggunakan intonasi suara serak-serak basah, sesekali keras dan sesekali melemah. Hal ini, bertujuan untuk menciptakan suasana perenungan yang betul-betul menyentuh agar pasien rehab ikut larut dalam perenungan tersebut.

${ }^{17}$ Ustadz Syaiful, Direktur Utama Yayasan Suci Hati, Wawancara Langsung, Padang, 10 Juni 2016

18 Rila, Pengasuh Yayasan Suci Hati, Wawancara Langsung, Padang, 17 Februari 2016
Adakalanya proses pelaksanaan muhasabah diawali dengan ice breaking dan bercanda gurau, kemudian setelah pasien larut dalam suasana gembira, secara perlahan-lahan pembicaraan diarahkan kepada suatu kejadian. Ustadz Syaiful pun bercerita tentang kejadian tersebut, sehingga menggiring alam berfikir para pasien rehab sesuai keinginan pemandu muhasabah. Setelah suasana larut dalam perenungan, pemandu mulai menanamkan nilai-nilai keimanan.

Tidak sebatas itu saja, proses perenungan juga kadangkala diawali dengan pemutaran film atau video. Film pilihan yang sudah disiapkan oleh pengasuh diputar menggunakan infocus. Menurut Rila, muhasabah melalui film lebih efektif untuk menciptakan suasana hati yang lembut dan mudah disentuh. Biasanya, pada momen yang tepat pemandu menanyakan pesan yang disampaikan di dalam film tersebut, sehingga sesekali pasien rehab menjawab dalam keadaan terisak tangis, saat itulah momen yang tepat untuk memberikan penanaman nilai-nilai karakter terhadap pecandu.

\section{Hasil}

Berdasarkan pelaksanaan kegiatan muhasabah yang telah penulis uraikan di atas, penulis melihat bahwa hasil pelaksanaan program muhasabah berjalan dengan lancar. Mentor melaksanakan muhasabah setelah shalat maghrib dalam satu bulan sekali. Hal ini diharapkan agar pecandu mendapat renungan dan terus diingatkan untuk selalu berinstrospeksi. Meskipun demikian, penulis melihat masih ada yang perlu ditambahkan dalam program muhasabah ini, pertama akan lebih baik jika sesekali diundang orang tua atau wali para pecandu untuk mengikuti muhasabah. 
Hal tersebut menjadi salah satu upaya Yayasan agar setelah muhasabah terjalin suasana bathin yang hangat antara anak dengan orang tua atau sang wali, juga antara para orang tua dengan pihak Yayasan, sehingga dengan begitu, Yayasan Suci Hati akan terasa seperti rumah sendiri ataupun keluarga baru bagi para pecandu yang tinggal di asrama. Dalam hal ini, Abdullah Nasih Ulwan mengatakan bahwa salah satu upaya menyentuh hati anak adalah dengan tutur kata yang lembut saat berada di samping anak. ${ }^{19}$ Kedua, untuk menghilangkan kejenuhan dan adanya inovasi metode atau gaya muhasabah hendaknya sesekali dihadirkan mentor dari luar sehingga tercipta suasana muhasabah yang berbeda.

\section{SIMPULAN}

Berdasarkan hasil penelitian dan analisis data yang penulis laksanakan di Panti Asuhan Rehabilitasi Sosial Pecandu Narkotika di bawah naungan Yayasan Suci Hati - Satu lembaga yang fokus menangani Eks-Pecandu di Kota Padang dalam upaya rehabilitasi melalui program muhasabah, Yayasan ini juga telah melakukan rehabilitasi terhadap pecandu narkotika sebanyak 230 pasien sejak mulai berdirnya (07 November 2008) -- yang beralamat di J1. Gunung Ledang RT. 005 RW.001 Kelurahan Banda Gadang, Kecamatan Nanggalo Kota Padang. Dari hasil penelitian terhadap 8 orang pengasuh serta 20 orang eks-pecandu yang telah direhabilitasi dapat diambil kesimpulan program muhasabah sebagai program awal pelaksanaan rehabilitasi eks- Pecandu adalah program yang tepat, sasaran program ini adalah kesadaran. Pasien dibimbing agar menyadari alasan mereka berada di tempat

19 Abdullah Nasih Ulwan, Cara Mendidik Anak dalam Islam, (Jakarta: Pustaka Armani, 1999), Cet. Ke-2, h. 217 rehabilitasi, kenapa mereka berada di sini, bagaimana sikap yang harus dimiliki, dan bagaimana output yang akan mereka bawa setelah selesai mengikuti rehabilitasi. Sasaran program muhasabah adalah mengembalikan kesadaran beraqidah yang benar, dengan begitu iman dan takwa akan tertanam kuat di dalam hati mereka, sehingga benteng pertahanan mereka saat kembali di masyarakat dan bergaul bersama lingkungaannya dapat mengendalikan dan meminimalisir pelanggaran hukum dan agama yang pernah mereka lakukan sebelumnya.

\section{REFERENSI}

Abd al-Baz. (2005). Tahqiq Shahih alBukhari. Beirut: Dar al-Fikr.

Adi, K. (2009). Diversi Sebagai Upaya Alternative Penanggulangan Tindak Pidana Narkotika Oleh Anak. Malang: UMM Press.

al-Ghazali. (2001). Ihya 'Ulumuddin. Terj. Muhammad Rahmat. Bandung: Penerbit Marja'.

Ali, M. D. (2001). Pendidikan Agama Islam. Jakarta: PT. Raja Grafindo Persada

al-Maududi, A. A. (2004). Dasar-Dasar Islam Terj. Ainur Rahmah. Bandung: Pustaka.

Azhar, M. A. (2015). "Kasus Narkoba di Sumbar". Padang: Sumatera Metropolitan.

Badan Narkotika Propinsi Sumatera Barat. (2010). Kebersamaan Memerangi Penyalahgunaan dan Peredaran Gelap Narkoba. Padang: BNNP.

BNK Padang. (2015). Buku Panduan "Pencegahan Penyalahgunaan 
Nidhomul Haq Vol 3 No: 1 Maret 2018

ISSN 2503-1481

Peredaran Gelap Narkotika.

Padang: BNK Padang

Chabib, H. T. (2005). Kapita Selekta

Pendidikan Islam. Yogyakarta: Pustaka Pelajar.

Depdikbud. (2008). Kamus Besar Bahasa Indonesia. Jakarta: Balai Pustaka.

Majid, N. (2014). Islam Doktrin dan Peradaba. Jakarta: Yayasan Wakaf Paramadina.

Muhaimin. (2006). Nuansa Baru Pendidikan Islam. Jakarta: PT. Raja Grafindo Persada.

Purwanto, N. (2003). Ilmu Pendidikan Praktis dan Teoritis. Bandung: PT. Remaja Rosda Karya

Rony, A. (2001). Alat Ibadah Muslim Koleksi Museum Adhityawarman. Padang: Bagian Proyek Pembinaan Permuseuman Sumatera Barat.
Sabiq, S. (2009). Fiqih Sunnah. Terjemah: M. Ali Nursyidi. Bandung: PT.AlMa'arif.

Sartito. (2000). Pengantar Psikologi. Jakarta: Bulan Bintang.

Sihab, Q. (2004). Tafsir al-Misbah. Bandung: Mizan.

Sudarsono. (2008). Kenakalan Remaja; Prevensi, Rehabilitasi, dan Resosialisasi. Jakarta: Rineka Cipta.

Syamsuridzal. (2006). Keluarga Anti Narkoba. Jakarta: Kompas Press.

Uhbiyati, dkk. (2001). Ilmu Pendidikan. Jakarta: Rineka Cipta.

Undang-Undang Narkotika. (2005).

Bandung: Citra Umbara 